\title{
鋭敏化ステンレス鋼・中性塩化物環境における 応力腐食割れ生起臨界条件*
}

\author{
中山 元 $^{* *}$, 梁 成浩 ${ }^{* * *}$, 明石正恒** \\ ** 石川島播磨重工業株式会社技術研究所 \\ *** 大連理工大学
}

\section{Repassivation Method for Determining the Critical Potential for Initiation of Stress-Corrosion Cracking*}

\author{
Guen Nakayama**, Chenghao Liang*** and Masatsune Akashi** \\ ** Ishikawajima-Harima Heavy Industries Co., Ltd. \\ *** Dalian University of Technology
}

\begin{abstract}
One point of technological importance in the use of stainless steels for natural water environments such as sea and fresh waters lies with their liability to stress-corrosion cracking. The stress-corrosion crack initiation in these environments is almost always via localized corrosion such as pitting or crevice-corrosion. Although the critical potentials for initiation of pitting and corrosion-crevice have been clearly defined and the experimental method of determination has been well standardized, neither definition nor standard method has been established for stress-corrosion cracking. In this paper, the critical conditions for initiation of the kind of stress-corrosion crack that originates from a corrosioncrevice have been discussed with intergranular stress-corrosion cracking occuring in the sensitied Type 304 stainless steel/neutral chloride solution environment system as an example. Following conclusions were drawn : (1) The repassivation potential for stress-corrosion cracks, $E_{R}$, scc, can be determined in the cyclic polarization tests using a specimen

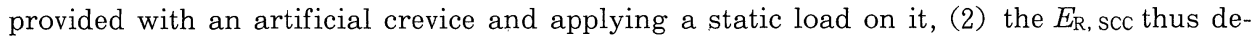
termined was about $100 \mathrm{mV}$ lower than the repassivation potential for corrosion-crevice, $E_{\mathrm{R}, \text { CREV }}$, determind for the same specimen but with no load applied, (3) effects of applied stress, degree of sensitization, test temperature, and $\mathrm{NaCl}$ concentration on $E_{\mathrm{R}}$, scc were documented, and (4) the $E_{\mathrm{R}}$, scc agreed with the critical potential for initiation of stresscorrosion cracking, $V_{\mathrm{C}}, \mathrm{scc}$, determined in the potentiostatic holding test.
\end{abstract}

Key words : stress-corrosion cracking, corrosion-crevice, sensitied stainless steel, critical potential for initiation of stress-corrosion cracking, repassivation method

\section{1. 緒 言}

耐食金属材料としてのステンレス鋼は装置材料として 多用されてきているが, 応力腐食割れは, 粒界腐食とと もに，ステンレス鋼の使用開始当初からの問題であっ て,この材料の使用上の重大な欠点とされていた。 歴史的な応力腐食割れ実験室加速試験液として沸騰,

* 腐食防食' 91, '95（東京, 1991 年, 1995 年）で発表

** T135 東京都江東区豊洲 3-1-15（3-1-15, Toyosu, Koto-ku, Tokyo, 135 Japan)

*** T116012 遼寧省大連市中山路 158 号 (158, Zhongsban Street, Dalian, .116012 China)
濃厚 $\mathrm{MgCl}_{2}$ 試験液 $^{1)}$ が広く使用されてきたが，オース テナイト・ステンレス鋼のき裂発生状況は直接貫入型 ${ }^{2}$ であって，このような苛酷な酸性環境は本来ステンレス 鋼が使用されるべき環境ではない。実構造物の装置材料 として海水, 淡水等の自然水系など比較的マイルドな環 境でステンレス鋼は使用されているが, 自然水環境に必 ず含まれる塩化物イオンはステンレス鋼に粒界応力腐食 割れをもたらす代表的な有害イオンである。応力腐食き 裂発生下限界応力は概して低く ${ }^{3)}$, SUS 304 ステンレ 鋼のそれは数 $\mathrm{MPa}$ 程度であって, 材料の降伏強さ

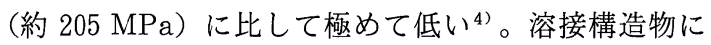




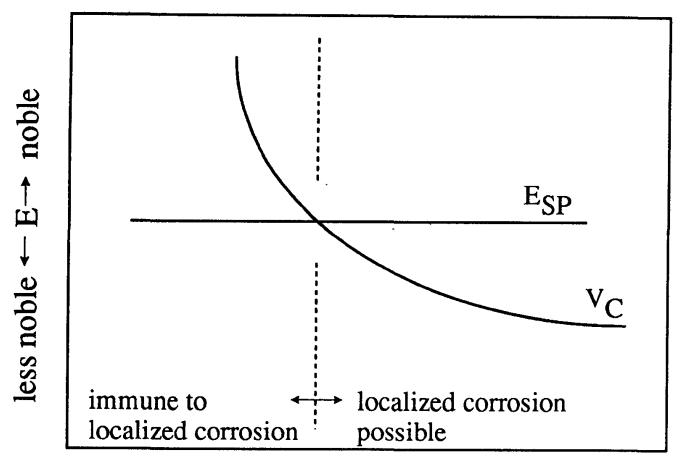

Chloride concentration

Fig. 1 Determination of usable condition for a material on comparison of its critical potential for localized corrosion, $V_{\mathrm{C}}$, and the free-corrosion potential, $E_{\mathrm{SP}}$ (schematic).

あっては, 特殊な場合を除いて, 溶接部近傍に材料の降 伏強さを超えた溶接残留応力 ${ }^{4)}$ が必ず存在していること から SUS 304 ステンレス鋼溶接構造物は応力腐食割れ 発生のための力学的条件を常に満足している ${ }^{5)}$ 。さら に, 溶接による鋭敏化, および, 構造上の, あるいは付 着物下のすきま構造の存在は不可避であるから, 孔食よ りも専らすきま腐食経由型の応力腐食割れ発生の条件を 満たすことになる。

特定の環境/材料の組み合せごとに孔食, すきま腐 食, 応力腐食割れのそれぞれの臨界電位が存在し, これ 以下の（これより卑な）電位域で材料を使用すれば局部 腐食発生の可能性はない。Fig. 1 に模式的に示すよう に, 局部腐食臨界電位, $V_{\mathrm{C}}$, と当該材料の当該環境系 における自然腐食電位， $E_{\mathrm{SP}}$ ，とを比較することにより 当該環境における当該材料の可使用条件を明らかにする ことができる。すなわち， $E_{\mathrm{SP}}$ が $V_{\mathrm{C}}$ よりも高い電位域 では局部腐食の可能性があるが, $E_{\mathrm{SP}}$ が $V_{\mathrm{C}}$ よりも低い 電位域ではその可能性はない。

$V_{\mathrm{C}}$ は定電位保持試験で局部腐食が生起しなくなる下 限界の電位として本来定義される ${ }^{6), 7)}$ 。従って, 動電位 分極曲線において, 局部腐食の生起/進展に対応して腐 食電流が急激に立ち上がる電位としての動電位法局部腐 食発生電位, $V^{\prime} \mathrm{c}$ ，とは区別される ${ }^{7)}$ 。ただし孔食の場 合には, 動電位法における電位送り速度が十分遅ければ 通常は $V^{\prime} \mathrm{c}$, PIT で代表できる。一方, すきま腐食の場合 は定電位保持法で求めたすきま腐食臨界電位, $V_{\mathrm{C}, \mathrm{CREV}}$, は動電位法で求めた $V^{\prime} \mathrm{C}, \mathrm{CREV}$ と一致しないが, すでに 進展しつつある腐食すきまの進展が停止する電位として の腐食すきま再不動態化電位, $E_{\mathrm{R}, \mathrm{CREV}}$, と本質的に一 致するる ${ }^{8)}$ 。 $E_{\mathrm{R}, \mathrm{CREV}}$ ，はすきま試験片を貴な電位まで 電位を走査して腐食すきまを発生・成長させた後, 電位
を逆走引して進展している腐食すきま部が再不働態化す ることによって成長性を失う電位としてマイクロコン ピューターによる自動化測定により実験的に求められ る9), 10)。

孔食, すきま腐食と同様に, 応力腐食割れの場合にも その生起臨界電位; $V_{\mathrm{C}, \mathrm{scc}}$, が明確に存在 ${ }^{11)}$ 15)する。 辻川ら ${ }^{13)}$ は $80^{\circ} \mathrm{C}$ の $\mathrm{NaCl}$ 環境における溶体化 SUS 316 ステンレス鋼のすきま付き DCB 試験片の定電位保持試 験を実施し，すきま試験片における応力腐食き裂発生臨 界電位は当該腐食すきま再不働態化電位と本質的に一致 することを示した。すなわち，自由面試験片あるいはす きま試験片における応力腐食き裂発生臨界電位は孔食再 不動態化電位, $E_{\mathrm{R}, \mathrm{PIT}}$ あるるい $E_{\mathrm{R}, \mathrm{CREV}}$ とそれぞれ一 致する ${ }^{15)}$ 。従って, $E_{\mathrm{SP}}$ と $E_{\mathrm{R}, \mathrm{CREV}}$ とを比較することに よって, 第一義的なステンレス鋼の可使用領域 ${ }^{16)}$ が決定 される。 $70^{\circ} \mathrm{C}$, 中性環境での SUS 304 ステンレス鋼の $E_{\mathrm{SP}}=0.32 \mathrm{~V}$ vs. SHE${ }^{17)}$ と, $E_{\mathrm{R}, \mathrm{CREV}}$ の塩化物濃度依存 性 ${ }^{16)}$ から可使用塩化物濃度が $\left[\mathrm{Cl}^{-}\right] \mathrm{c}, \mathrm{CREV}=20 \sim 30$ $\mathrm{ppm}^{16)}$ 之判定される。しかしながら，実際にはこれら 臨界条件を超える条件で装置材料はしばしば応力腐食割 れを経験することなく安全に使用されている。これは割 れ生起が可能であってもその生起確率が低いことおよ び/もしくはその寿命が長いことによる。したがって, 装置材料の応力腐食割れパフォーマンスを定量的に予測 するためには，まずき裂発生臨界条件を定量化すること が重要であるが, それだけでは十分ではなく, 応力腐食 割れ発生寿命の取り扱いが重要である。

Evans ら ${ }^{18)}$ が最初に指摘した通り腐食現象が本質的 に確率的性格を有していることから, 応力腐食割れ生起 寿命の定量的評価には確率論的なアプローチの導入が必 要で, 鋭敏化ステンレス鋼の粒界応力腐食割れ破断寿命 分布は同一条件の大繰返し数試験を行って指数分布モデ ル19) 22)で記述される。

以上のことから，実環境における応力腐食割れに正し く対処するためには，局部腐食からのき裂発生条件に対 する正当な理解が不可欠である。これらの背景から，本 稿は, 工学的に重要な鋭敏化ステンレス鋼/中性塩化物 環境系の粒界応力腐食割れを例として, 局部腐食からの き裂発生臨界条件について検討する。

\section{2. 試験 方 法}

\section{1 供試材および熱処理}

Table 1 に化学成分を示す直径 4 inch の SUS 304 ス テンレス鋼管を供試材として, Table 2 に示す $\mathrm{A} \sim \mathrm{E}$ の 5 種類の熱処理を施した後, 機械加工により管長手方向 に試験片を採取した。試験片はその平行部寸法が $5 \mathrm{~mm}$ $\phi \times 10 \mathrm{mmL}$ の丸棒引張試験片とし, 試験片表面を 
Table 1 Chemical composition of tested pipe (mass\%)

\begin{tabular}{|c|c|c|c|c|c|c|}
\hline $\mathrm{C}$ & $\mathrm{Si}$ & $\mathrm{Mn}$ & $\mathrm{P}$ & $\mathrm{S}$ & $\mathrm{Ni}$ & $\mathrm{Cr}$ \\
\hline 0.045 & 0.36 & 0.91 & 0.030 & 0.002 & 8.26 & 19.19 \\
\hline
\end{tabular}

\# $100 \mathrm{SiC}$ 而水研磨紙で湿式研磨した後脱脂, 洗浄後, 平行部に幅約 $8 \mathrm{~mm}$ の PTFE 滤紙を Convex 冶具によ り固定することによって人工すきまを形成した。なお， 一部の試験片は試験後の表面観察のためにバフ研磨まで 実施した。

\section{2 鋭敏化度; $R_{\mathrm{a}}$ の測定}

各試験片の鋭敏化の程度を定義する目的で, JIS G 0580 に従って, EPR 試験を実施した。丸棒引張試験片 のネジ部から小片を採取し, 試験片断面が電極面となる ように樹脂に埋め込み, リード線をとったものを試験電 極とした。脱気された $30^{\circ} \mathrm{C} の 0.5 \mathrm{kmol} / \mathrm{m}^{3} \mathrm{H}_{2} \mathrm{SO}_{4}+$ $0.01 \mathrm{kmol} / \mathrm{m}^{3} \mathrm{KSCN}$ 水溶液環境において, $6 \mathrm{~V} / \mathrm{h} の$ 電位送り速度での往復分極実験を行い, 復路と往路との 分極曲線における極大電流值, $i_{\mathrm{a}}$, および $i_{\mathrm{r}}$ の比として の再活性化率, $R_{\mathrm{a}}$, として各試験片の鋭敏化度を評価 した。

$$
R_{\mathrm{a}}=i_{\mathrm{a}} / i_{\mathrm{r}}
$$

なお, 本測定においては各条件ごとに 5 回の絽返し実験 を行い, 得られた再活性化率デー夕の平均值をもって各 試験片の鋭敏化度, $R_{\mathrm{a}}$ ，とした。

\section{3 腐食すきま再不働態化電位 ; $\boldsymbol{E}_{\mathrm{R}, \mathrm{CREV}}$ の測定}

標準的な方法 ${ }^{15)}$ に従って, 脱気された $20 \sim 80^{\circ} \mathrm{C}$ の $0.035 \sim 3.5 \% \mathrm{NaCl}$ 水溶液環境において $E_{\mathrm{R}, \mathrm{CREV}}$ を求め た。丸棒引張試験片の平行部に人工すきまを付与し, リード線をとったものを試料電極とした。i）所与の試 験環境に試験片電極を浸漬後, ii）貴方向に $20 \mathrm{mV} /$ min の電位送り速度で動電位分極し腐食すきまを生起 せしめ, iii）腐食すきまの進展に対応する腐食電流 200 $\mu \mathrm{A}$ に達した時点でその電流值に $2 \mathrm{~h}$ 定電流保持して腐 食すきまを十分に進展させた。次いで，iv）反対の卑な 方向に $10 \mathrm{mV} / \mathrm{min}$ の電位送り速度で動電位分極し,

v）腐食電流值が $50 \mu \mathrm{A}$ に達した時点で定電位保持に切 り替えた。vi）定電位保持中に腐食すきま進展の継続に 対応する腐食電流の上昇傾向が認められた場合には, 保 持電位をさらに $10 \mathrm{mV}$ 卑な電位にした。vii）この操作 を繰り返して, viii） $2 \mathrm{~h}$ の定電位保持期間中に腐食電 流の上昇傾向が認められなくなる最も貴な電位をもって $E_{\mathrm{R}, \mathrm{CREV}}$ とした。

\section{4 応力腐食き裂再不働態化電位; $\boldsymbol{E}_{\mathrm{R}}, \mathrm{scc}$ の測定}

$\left.i^{\prime}\right)$ 所与の試験環境において人工すきま付丸棒引張試 験片に対してばね式定荷重付与装置を用いて設計降伏点 $\mathrm{Sy}(=207 \mathrm{MPa})$ の 2.0，1.75 あるいは 1.5 倍の静的荷
Table 2 Heat treatment conditions and the degree of sensitization determined by the EPR test.

\begin{tabular}{|c|l|c|}
\hline Specimen & Heat Treatment & Degree of Sensitization, $\mathrm{R}_{\mathrm{a}}$ \\
\hline $\mathrm{A}$ & $1060^{\circ} \mathrm{C} / 0.5 \mathrm{~h} / \mathrm{WQ} \quad(\mathrm{S} \mathrm{A})$ & 0.005 \\
\hline $\mathrm{B}$ & \multirow{2}{*}{$\mathrm{S} \mathrm{A}+750^{\circ} \mathrm{C} / 1 \mathrm{~h}+500^{\circ} \mathrm{C} / 24 \mathrm{~h}$} & 0.310 \\
\cline { 1 - 1 } $\mathrm{B}^{\prime}$ & & 0.460 \\
\hline $\mathrm{C}$ & $\mathrm{SA}+600^{\circ} \mathrm{C} / 24 \mathrm{~h}$ & 0.375 \\
\hline $\mathrm{D}$ & $\mathrm{S} \mathrm{A}+600^{\circ} \mathrm{C} / 2 \mathrm{~h}$ & 0.280 \\
\hline $\mathrm{E}$ & $\mathrm{S} \mathrm{A}+600^{\circ} \mathrm{C} / 0.5 \mathrm{~h}$ & 0.130 \\
\hline
\end{tabular}
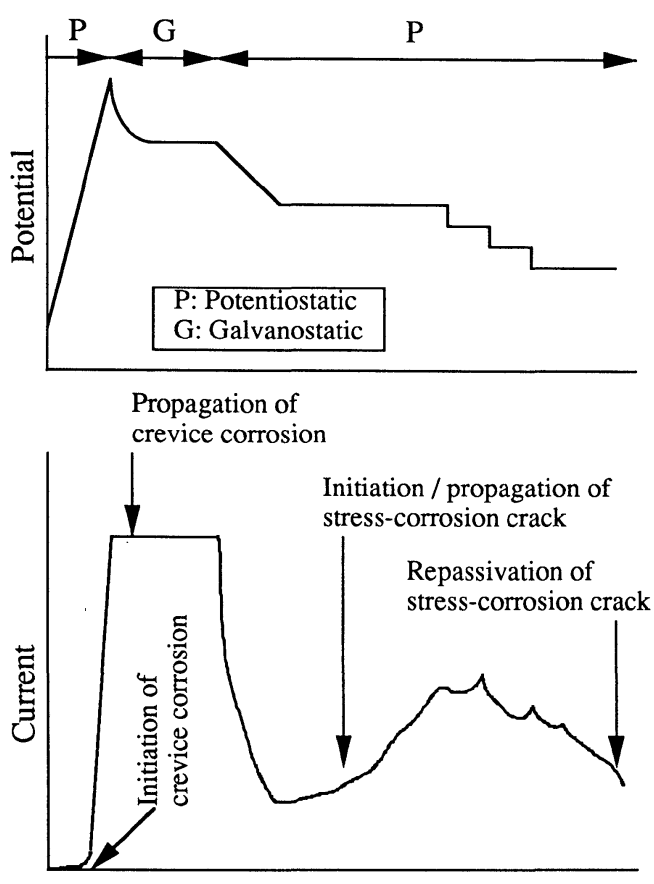

Time

Fig. 2 History of controlling the electrode potential and the change of corrosion current during the course of $E_{\mathrm{R}, \mathrm{scc}}$ determination experiment (schematic).

重を付与して, $E_{\mathrm{R}, \mathrm{CREV}}$ と同様な往復分極実験によって $E_{\mathrm{R}} \mathrm{scc}$ を決定した。ただし， $\mathrm{v}^{\prime} ） 50 \mu \mathrm{A}$ で $48 \mathrm{~h}$ 定電流 保持して, 腐食すきま活性先端から応力腐食き裂を生起 ・進展せしめた。なお, 試験当初より荷重を付与したと ころ測定中に試験片が破断に至る場合があったため,一 部の強鋭敏化材の試験については $200 \mu \mathrm{A}$ の定電流保持 終了前の適当なタイミングで所与の静的荷重を負荷し た。電位操作を繰り返して, viii' $) 2 \mathrm{~h}$ の定電位保持期 間中に応力腐食き裂の進展に相当する電流の上昇傾向が 認められなくなる最も貴な電位をもって $E_{\mathrm{R}, \mathrm{scC}}$ とし た。実験における電位/電流の制御とそれに伴う電流/ 電位の変化を模式的に Fig. 2 に示す。 


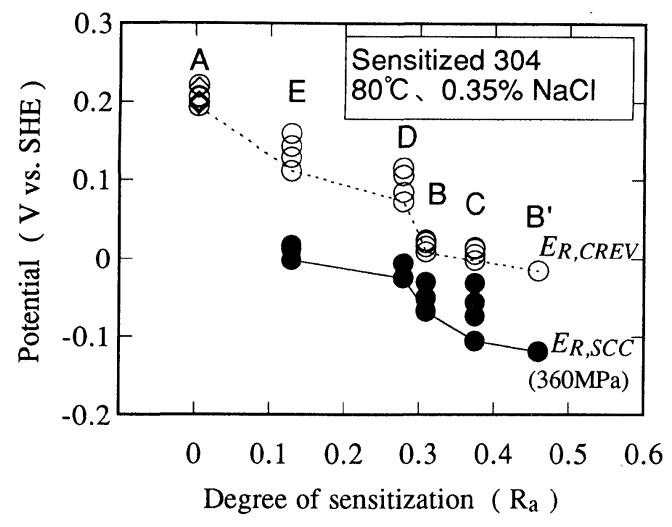

Fig. 3 Effects of the degree of sensitization (as given by the reactivation ratio, $R_{a}$, determined by the EPR test on $E_{\mathrm{R}, \mathrm{CREV}}$ (open) and $E_{\mathrm{R}, \mathrm{scc}}$ (solid).

\section{5 定電位·定荷重試験による応力腐食割れ破断寿} 命

同一の人工すきま付与試験片を多連型ばね式応力腐食 割れ試験装置 ${ }^{19)}$ にセットし, ポテンショスタットを用い て所与の電位に定電位・定荷重保持を行った。試験片に 取り付けられた試験槽には，これに接続された薬液循環 装置により大気に平衡した試験溶液が循環供給され, 実 測溶存酸素濃度は約 $6 \mathrm{ppm}$ であった。試験片を荷重付 与装置に取り付け, 溶液を循環させたと同時にポテン ショスタットを用いて $E_{\mathrm{R}, \mathrm{scc}}$ 以下の卑な電位に定電位 保持を行いながら所与の荷重を付与した後に, 所与の電 位に定電位・定荷重保持を行う。試験中は電流の变化の モニターを行い, 試験片の応力腐食き裂発生, 進展, お よび破断に相当する急激な電流の増加をもって破断寿命 (時間) を決定した。得られた個々の破断寿命は指数分 布確率プロットを行った。すなわち, 指数分布モデ ル ${ }^{19)}$ 22) における応力腐食割れ生起の累積確率, $F(t)$, の時間, $t$, 依存性（累積分布関数）は次式で表される。

$$
\begin{aligned}
& F(t)=1-\exp [-(t-a) / \theta] ; t \geqq a \\
& =0 \quad t<a \\
& a \text { : 位置パラメー夕（寿命分布下限界值） } \\
& \theta \text { : 尺度パラメータ（標準偏差） }
\end{aligned}
$$

$F(t)$ と累積故障率, $H(t)$, との関係は,

$$
F(t)=1-\exp [-H(t)]
$$

従って, $H(t)$ と $t$ との関係は,

$$
H(t)=(t-a) / \theta
$$

の線形関係式で表される。指数確率紙上にデータをプ ロットし, 直線を当てはめ, 直線の $t$ - 接片から $a$, 直 線の勾配から $\theta$ を得る。プロットへの直線の当てはめ, すなわちパラメータの推定には線形不偏推定子法 ${ }^{21)}$ を用 いた。

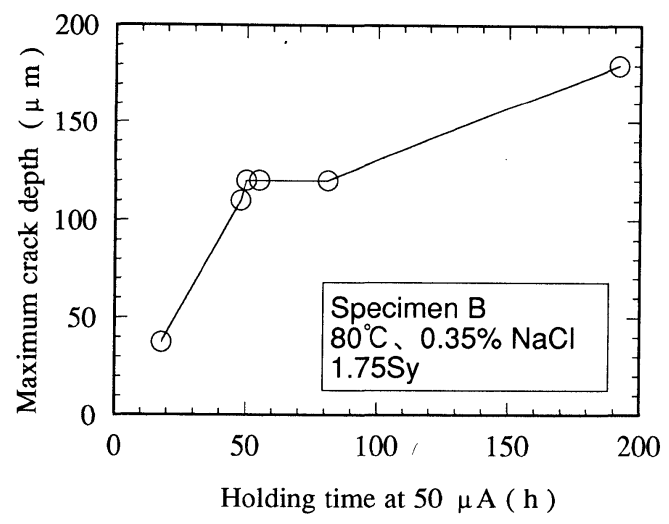

Fig. 4 Effects of the potentiostatic holding time on the maximum depth of stress-corrosion crack found in specimen $\mathrm{B}$ as tested in $80^{\circ} \mathrm{C}, 0.35 \% \mathrm{NaCl}$ solution environment with the switch over current of $50 \mu \mathrm{A}$.

\section{3. 結果および考察}

\section{1 材料の鋭敏化度と $\boldsymbol{E}_{\mathrm{R}, \mathrm{CREV}}$ との関係}

$\mathrm{EPR}$ 試験で決定された材料の鋭敏化度 $\left(R_{\mathrm{a}}\right)$ と $80^{\circ} \mathrm{C}, 0.35 \% \mathrm{NaCl}$ 水溶液環境で決定された $E_{\mathrm{R}, \mathrm{CREV}}$ お よび後述の $E_{\mathrm{R}, \mathrm{scc}}$ との関係を各々 Fig. 3 の○, ○印で 示す。 $R_{\mathrm{a}}$ の増加とともに $E_{\mathrm{R}, \mathrm{CREV}}$ が卑になって, $R_{\mathrm{a}}>$ 0.3 から飽和した。なお, B 熱処理は, 熱処理のロット によって鋭敏化度が異なったため， B, B'として区別し た。鋭敏化熱処理によって形成された $\mathrm{Cr}$ 欠乏域の存在 が腐食すきまの再不動態化を妨げた結果腐食すきま再不 動態化電位が低くなったものと考えられる。

\section{$3.2 \boldsymbol{E}_{\mathrm{R}, \mathrm{scc}}$ の決定}

$80^{\circ} \mathrm{C}$ の $0.35 \% \mathrm{NaCl}$ 水溶液環境において $1.75 \mathrm{Sy} に$ 相当する $360 \mathrm{MPa}$ の定荷重を負荷した熱処理 B 試験片 に対して, $\mathrm{v}^{\prime}$ ) $50 \mu \mathrm{A}$ での定電流保持時間を 18〜192 h の範囲で変化させた場合の定電流保持時間と試験後の最 大き裂深さとの関係を Fig. 4 に示す。定電位保持時間 が $40 \mathrm{~h}$ 以上の場合にはき裂深さが $50 \mu \mathrm{m}$ を超えている ことから, 以後の実験での $50 \mu \mathrm{A}$ での定電流保持時間 はすべて $48 \mathrm{~h}$ とした。鋭敏化ステンレス鋼/高温高純度 水環境系の応力腐食割れは近傍に発生した微小な応力腐 食き裂同士が合体してその深さが $50 \mu \mathrm{m}$ を越えるよう になって初めて進展性を有する ${ }^{23)}$ 。本環境系とは応力腐 食割れのメカニズムが異なる ${ }^{24)}$ が，ここでは特別な考察 を加えず $50 \mu \mathrm{m}$ のしきい值をそのまま適用した。なお,

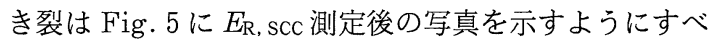
て腐食すきまを起点として結晶粒界に沿って進展してい た。 $80^{\circ} \mathrm{C}, \quad 0.35 \% \mathrm{NaCl}$ 水溶液環境における熱処理 $\mathrm{D}$ および $\mathrm{E}$ 試験片に対する $E_{\mathrm{R}}, \mathrm{SCC}$ の負荷応力依存性を Fig. 6 に示す。両熱処理試験片とも, 負荷応力 150 

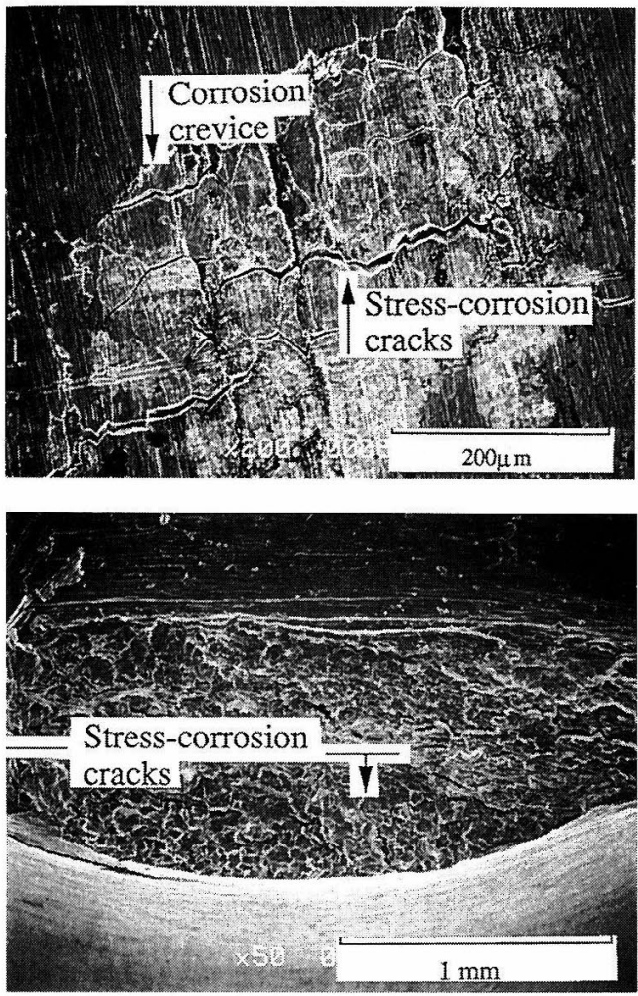

Fig. 5 Photograph the specimen after the measurement of the stress-corrosion cracks repassivation potential, $E_{\mathrm{R}}$, scc.

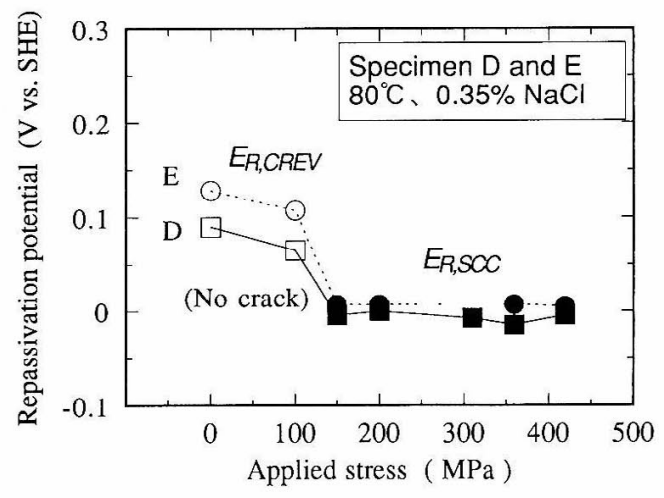

Fig. 6 Effects of applied stress on $E_{\mathrm{R}, \mathrm{scc}}$ of specimens $\mathrm{D}$ and $\mathrm{E}$ tested in $80^{\circ} \mathrm{C}, 0.35 \% \mathrm{NaCl}$ solution environment.

$\mathrm{MPa}$ 以上では応力腐食き裂再不動態化電位測定値に負 荷応力依存性は認められない。これから，以後の実験に おいては $1.75 \mathrm{Sy}$ （360 MPa）を負荷応力とした。また， 負荷応力 $100 \mathrm{MPa}$ においては, 実験後にき裂発生は認 められず無負荷試験片のそれと同じ電位を示したことか

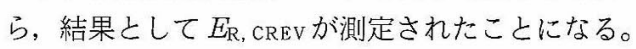

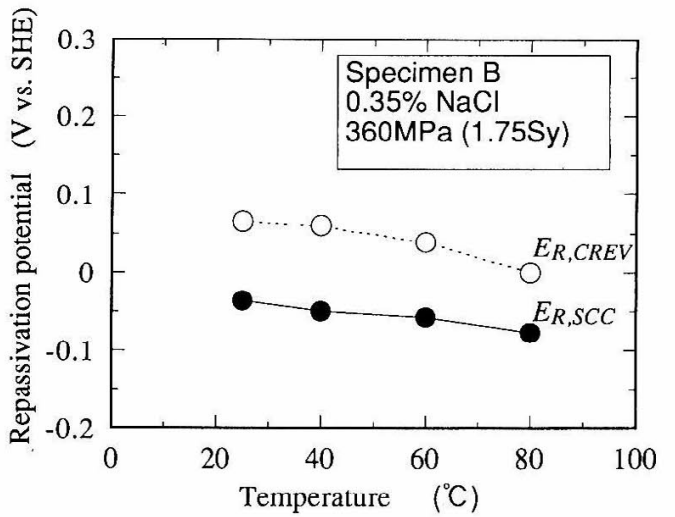

Fig. 7 Effects of temperature on $E_{\mathrm{R}, \mathrm{CREV}}$ and $E_{\mathrm{R}}$, scc of specimen $\mathrm{B}$ in $0.35 \% \mathrm{NaCl}$ solution environment.

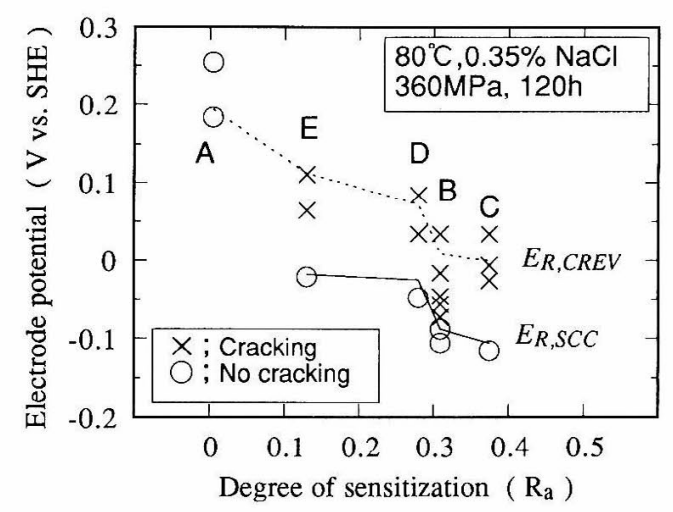

Fig. 8 Effects of heat treatment on $E_{\mathrm{R}, \mathrm{CREV}}$ and $E_{\mathrm{R}, \mathrm{scc}}$ of specimens $\mathrm{A}$ to $\mathrm{E}$ in $80^{\circ} \mathrm{C}, 0.35 \%$ $\mathrm{NaCl}$ solution environment delineating regions of cracking (crosses) and no cracking (circles) under potentiostatic holding.

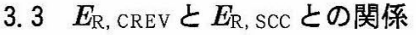

鋭敏化度 $\left(R_{\mathrm{a}}\right)$ と $80^{\circ} \mathrm{C}, \quad 0.35 \% \mathrm{NaCl}$ 水溶液環境で 決定された $E_{R, C R E V}(O)$ ， あるいは $E_{R, S C C}(\mathbf{O})$ との関 係を Fig. 3 に示したように, 前者に比して後者は約 100 $\mathrm{mV}$ 低い傾问にある。また，熱処理 B 試験片に対する $E_{\mathrm{R}, \mathrm{CREV}}(\bigcirc)$ および $E_{\mathrm{R}, \mathrm{SCC}}(\mathbf{O})$ の試験温度依存性を Fig. 7 に示す。実験の範团内において, $E_{R}, \mathrm{CREV}$, $E_{\mathrm{R}}, \operatorname{scc}$ はともに試験温度の上昇とともに低くなる傾向 が認められ, 同様に, 前者に比して後者は約 $100 \mathrm{mV}$ 低 い。

\section{$3.4 E_{\mathrm{R}, \mathrm{scC}}$ と $V_{\mathrm{C}, \mathrm{scC}}$ との関係}

$80^{\circ} \mathrm{C}, 0.35 \% \mathrm{NaCl}$ 水溶液環境の熱処理 $\mathrm{A} \sim \mathrm{E}$ 試験 片の $120 \mathrm{~h}$ の定電位保持試験における応力腐食き裂発生

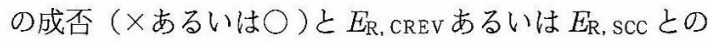
対比を Fig. 8 に示す。 $E_{\mathrm{R}, ~} \mathrm{scC}$ より低い電位域では応力 


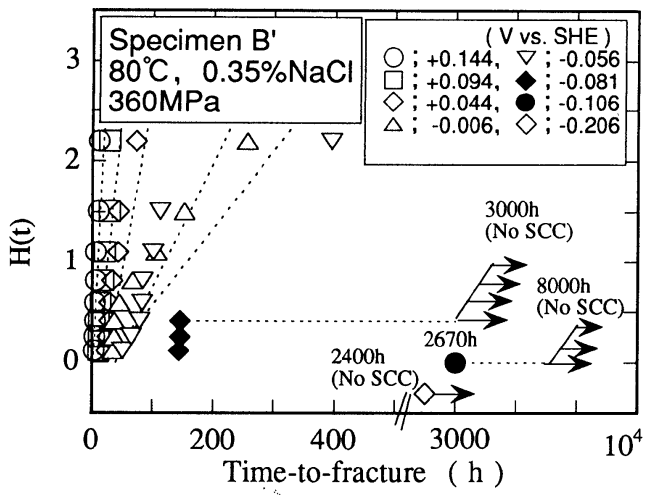

Fig. 9 Effects of applied potential on the life-time distribution of specimen $\mathrm{B}^{\prime}$ in $80^{\circ} \mathrm{C}, 0.35 \%$ $\mathrm{NaCl}$ solution environment.

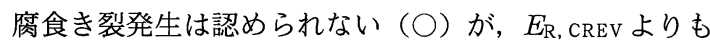
低くても $E_{\mathrm{R}, \mathrm{scc}}$ より高い電位域では応力腐食き裂発生 が観察 (メ) されている。

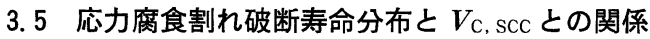

$80^{\circ} \mathrm{C}, 0.35 \% \mathrm{NaCl}$ 水溶液環境の熱処理 $\mathrm{B}^{\prime}$ 試験片の 応力腐食割れ破断寿命の付与電位依存性を指数確率プ ロットとして Fig. 9 に示す。プロットは良い直線関係 を示し，定電位試験による寿命分布は指数分布モデルに 近似できる。また，付与電位の低下とともに， $a$ および $\theta$ がともに増大し, 長時間側で直線からはずれる傾向が 見られるとともに，更に電位を低下させると試験した $2400 \mathrm{~h}, 3000 \mathrm{~h}$ でいずれも応力腐食割れ破断しなかっ た。 $80^{\circ} \mathrm{C}$ の $0.35 \% \mathrm{NaCl}$ 水溶液環境の熱処理 $\mathrm{B}^{\prime}$ 試験 片の $a$ の付与電位; $E$, 依存性を $E_{\mathrm{R}, \mathrm{CREV}}$ あるいは $E_{\mathrm{R}}, \mathrm{scc}$ 対比させて Fig.10 に示す。 $E_{\mathrm{R}, \mathrm{CREV}}$ よりも貴 な電位域では付与電位の低下に従って $a$ は増大する。

一方, $E_{\mathrm{R}, \mathrm{sCC}}$ 以上 $E_{\mathrm{R}, \mathrm{CREV}}$ 以下の電位域では, 付与電位 の低下とともに $a$ は急速に伸びて, 実験の範囲内では, $E_{\mathrm{R}, \mathrm{scc}}$ 以下の電位域では応力腐食割れ感受性を示さな くなる。従って, 応力腐食き裂再不動態化電位は定電位 保持試験における応力腐食き裂発生下限界電位と一致し ていると見なせる。これらから，応力腐食き裂再不動態 化電位, $E_{\mathrm{R}, \mathrm{scc}}$ ，をもって鋭敏化ステンレス鋼の応力腐 食き裂生起臨界電位とし得る。

\section{3. $6 E_{R}, \operatorname{scc}$ 概念の確証}

上述の挙動は, $\mathrm{NaCl}$ 水溶液環境のステンレス鋼固溶 化焼鈍材のすきま付与試験片に対して, 腐食すきま再不 動態化電位と応力腐食き裂生起臨界電位とが一致するこ とを示した辻川らの結論 ${ }^{13), 15)}$ と矛盾している。 $E_{\mathrm{R}, \mathrm{CREV}}$ より低く $E_{\mathrm{R}, \mathrm{scc}}$ より高い電位域で実施された定電位保 持試験における応力腐食き裂発生箇所近傍にはきわめて 軽微なすきま腐食の兆候が認められた。上述のように

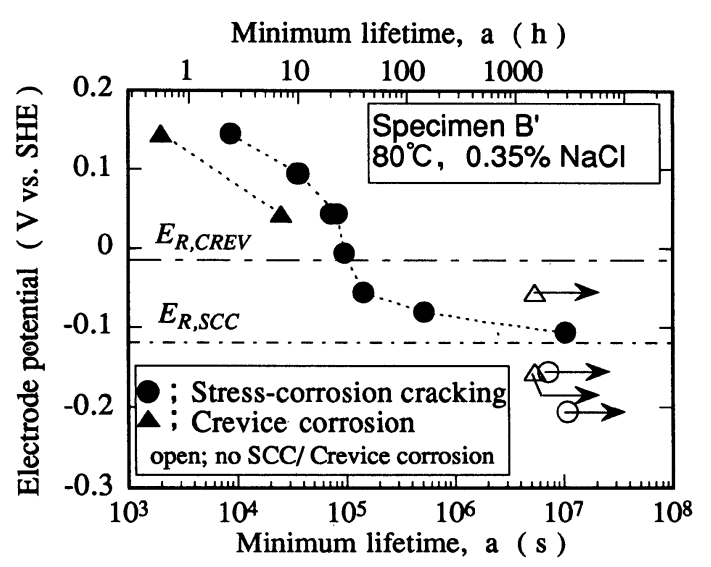

Fig. 10 Effects of electrode potential on lower limit life-time, $a, E_{\mathrm{R}, \mathrm{CREV}}$, and $E_{\mathrm{R}}$, scc of specimen $\mathrm{B}^{\prime}$ in $80^{\circ} \mathrm{C}, 0.35 \% \mathrm{NaCl}$ solution environment.

$E_{\mathrm{R}, \mathrm{CREV}}$ は腐食すきま生起臨界電位と本質的に一致して いるから，これよりも低い電位域においては腐食すきま の生起は不可能である。しかしながら，これはあくまで も進展性腐食すきまに対する規範であって, 臨界電位よ りも低い電位域においても非進展性の腐食すきまは生起

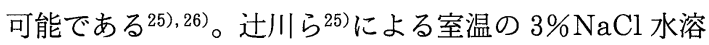
液環境における SUS 316 ステンレス鋼の場合には，非 進展性腐食すきまは定常進展のための臨界深さ $40 \mu \mathrm{m}$ を超えて進展することはなく，この非進展性腐食すきま の生起臨界電位, $E_{\mathrm{Z}, \mathrm{CREV}}$, は $E_{\mathrm{R}, \mathrm{CREV}}$ に比して約 100 $\mathrm{mV}$ 低い。これらから，本実験において $E_{\mathrm{R}, \mathrm{CREV}}$ より 低く $E_{\mathrm{R}, \mathrm{scc}}$ より高い電位域で実施された定電位保持試 験における応力腐食き裂発生はこのような非進展性腐食 すきまを起点として生起したものと考えられる。従っ $\tau$, 本実験結果は応力腐食き裂生起臨界電位が $E_{\mathrm{R}, \mathrm{CREV}}$ よりもむしろ $E_{Z, C R E V}$ に一致することを示唆する。

本実験結果と辻川らの結果 ${ }^{13), 15)}$ との矛盾が固溶化焼 鈍鋼の粒内応力腐食割れ之鋭敏化鋼の粒界応力腐食割れ との差異に起因するのか否かを含めて, これらの挙動に ついては今後のより詳細な検討が必要であろう。

\section{4. まと め}

鋭敏化ステンレス鋼 / 中性塩化物水溶液環境系の粒界 応力腐食割れを例として腐食すきまからの応力腐食き裂 生起臨界条件について検討した。結果を以下にまとめ る。

（1） 静的荷重と人工すきまとを付与した試験片に対 する往復分極実験によって, 応力腐食き裂再不動態化電 位， $E_{\mathrm{R}}, \mathrm{scc}$ ，を決定することができた。

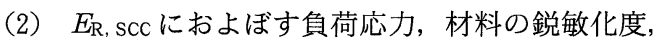


試験温度，および $\mathrm{NaCl}$ 濃度の影響を検討した。また， 得られた $E_{\mathrm{R}, \mathrm{scc}}$ は無負荷試験片に対して決定された腐 食すきま再不動態化電位， $E_{\mathrm{R}, \mathrm{CREV}}$ ，よりも約 $100 \mathrm{mV}$ 低い值であった。

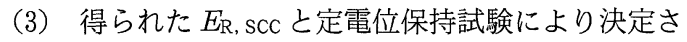
れた応力腐食き裂発生下限界電位, $V_{c}, s c c$, とよく一致 した。従って， $E_{R}, \operatorname{scc}$ をもって応力腐食き裂生起臨界 電位とし得る。

(Manuscript received July 30, 1995 ; in final form February 6, 1996)

\section{引用 文 献}

1) M. A. Scheil : Proc. Symp. Stress-Corrosion Cracking of Metals, p.395, ASTM/AIME, (1945).

2 ）辻川茂男：「第 78,79 回西山記念技術講座予講 集」, p.201, 日本鉄鋼協会, (1981).

3) 辻川茂男 :「腐食防食工学概論一理論と実際」, p. 37, 腐食防食協会, (1984).

4 ) 竹本幹男 : 高圧ガス, 20, 415 (1983).

5 ）コロージョン・セミナー企画委員会編 :「多管式 ステンレス鋼熱交換器の応力腐食割れ一第 2 次使 用実績調查結果と寿命解析一」, 化学工業社 (1984).

6 ) Y. Kolotyrkin : Corrosion, 19, 261 (1963).

7) H. P. Leckie and H. H. Uhlig : J. Electrochem. Soc., 113, 1262 (1962).

8 ）辻川茂男, 久松敬弘：防食技術，29，37（1980．

9 ）第 48 回腐食防食シンポジウム, 腐食防食協会, (1983).

10）第 103 回腐食防食シンポジウム, 腐食防食協会, (1995).
11）小若正倫，工藤赴夫 : 鉄と鋼，62，230（1976）.

12）遅沢浩一郎, 藤原最仁:「第 23 回腐食防食討論 会予講集」, p.63，腐食防食協会（1976）。

13）辻川茂男，玉置克臣，久松敬弘：鉄と鋼，66, 2067 (1980).

14）渡辺治幾, 前北杲彦：鉄と鋼， 67，S 421 (1981).

15）篠原正, 辻川茂男, 久松敬弘：防食技術，34, 283 (1985).

16) G. Nakayama, H. Wakamatsu \& M. Akashi : Proc. Mat. Res. Soc. Vol.294, p.323, Materials Research Society (1993).

17) T. Fukuda \& M. Akashi : Proc. NUCLEAR WASTE PACKAGING FOCUS'91, p. 201, ANS, (1991).

18) U. R. Evans, P. B. Mears, \& P. E. Queneau : Engineering, 136, 689 (1933).

19) G. Nakayama, M. Akashi \& A. Ohtomo : ISIJ International, 31, 223 (1991).

20）明石正恒，見城孝雄，松倉伸二，川本輝明：防食 技術，33，628(1984).

21）小若正倫，柘植宏之，明石正恒，正村克身，石本 裕保:「装置材料の寿命予測入門一極值統計の腐 食への適用」，腐食防食協会編，丸善（1984）.

22）明石正恒，大友 暁：材料，36，59 (1987).

23) M. Akashi : "Localized Corrosion-Current Japanese Materials Research, Vol. 4”, Ed. by F. Hine, K. Komai, and K. Yamakawa, p.175, Soc. Mat. Sci., Jpn, Elsevier Applied Science (1988)

24）腐食防食協会編：「金属の腐食・防食 Q\&A」, p. 166, 丸善, (1988).

25）辻川茂男, 広瀬幸雄, 岡山 伸, 久松敬弘 : 防食 技術，32，707（1983）.

26) S. Tsujikawa, \& K. Kojima : Proc. Mat. Res. Symp. Vol.212, p. 261 Materials Research Society (1991). 